\title{
Páramo Lakes of Colombia: An Overview of Their Geographical Distribution and Physicochemical Characteristics
}

\author{
Angela Zapata ${ }^{1, *}$, Carlos A. Rivera-Rondón ${ }^{1} \mathbb{1}$, Daivan Valoyes ${ }^{1}$, Claudia L. Muñoz-López ${ }^{1}$, \\ Marino Mejía-Rocha ${ }^{2}$ and Jordi Catalan ${ }^{3,4}$ \\ 1 Laboratorio de Limnología, Unidad de Ecología y Sistemática-UNESIS, Departamento de Biología, \\ Pontificia Universidad Javeriana, Bogotá 110231, Colombia; crivera@javeriana.edu.co (C.A.R.-R.); \\ dvaloyes@javeriana.edu.co (D.V.); cl.munoz@javeriana.edu.co (C.L.M.-L.) \\ 2 Instituto de Salud Pública, Pontificia Universidad Javeriana, Bogotá 110231, Colombia; \\ marino.mejia@javeriana.edu.co \\ 3 CREAF, Universitat Autònoma de Barcelona Campus, Edifici C, E-08193 Cerdanyola del Vallès, Spain; \\ j.catalan@creaf.uab.cat \\ 4 CSIC, Universitat Autònoma de Barcelona Campus, E-08193 Barcelona, Spain \\ * Correspondence: zapata-a@javeriana.edu.co
}

\section{check for} updates

Citation: Zapata, A.; Rivera-Rondón C.A.; Valoyes, D.; Muñoz-López, C.L.; Mejía-Rocha, M.; Catalan, J. Páramo Lakes of Colombia: An Overview of Their Geographical Distribution and Physicochemical Characteristics. Water 2021, 13, 2175. https:// doi.org/10.3390/w13162175

Academic Editors: Salvador Sánchez-Carrillo, Martín Merino-lbarra and Javier Alcocer-Durand

Received: 31 May 2021

Accepted: 20 July 2021

Published: 9 August 2021

Publisher's Note: MDPI stays neutral with regard to jurisdictional claims in published maps and institutional affiliations.

Copyright: (c) 2021 by the authors. Licensee MDPI, Basel, Switzerland. This article is an open access article distributed under the terms and conditions of the Creative Commons Attribution (CC BY) license (https:// creativecommons.org/licenses/by/ $4.0 /)$.

\begin{abstract}
The páramo lakes, Colombia, situated in the neotropical region, are of great value both as natural heritage and as water source to the most populated areas of the Andes, but are threatened by expanding agriculture, livestock, mining, and landscape fragmentation. Nonetheless, a general assessment of the lakes' distribution and biogeochemical characteristics was lacking. We made a complete inventory of the Colombian páramo lakes and characterized their morphometry and water chemistry based on a survey of 51 lakes in the Eastern Cordillera. There are 3250 lakes distributed across 28 páramo complexes in Colombia, mainly located between 3600 and $4400 \mathrm{~m}$ a.s.l. The lakes are usually small $(<10 \mathrm{ha})$ and shallow $(<10 \mathrm{~m})$. Most of them are slightly acidic (average $\mathrm{pH} 6)$, with high nutrient (total phosphorus $\sim 0.6 \mathrm{mg} / \mathrm{L}$, total nitrogen $\sim 1 \mathrm{mg} / \mathrm{L}$ ) and total organic carbon $(\sim 6 \mathrm{mg} / \mathrm{L})$ concentrations and low oxygen $(\sim 3.5 \mathrm{mg} / \mathrm{L})$ at the bottom. Water chemistry varies according to two main independent gradients related to watershed bedrock geology and trophic state. Global change pressures may be challenging the preservation of these unique ecosystems. Increasing the protection of more lake watersheds should reduce these potential impacts by mitigating negative synergies with local pressures.
\end{abstract}

Keywords: the Andes; conservation; global change; high mountain lakes; neotropics; trophic state; wetlands

\section{Introduction}

The páramo aquatic ecosystems are a unique element of the planet's natural heritage and are socially crucial because they provide water to the most densely populated areas of the neotropical region of Colombia [1]. The páramo extends across high mountains from Ecuador to Venezuela. In these areas, air temperature is relatively constant throughout the year and relative humidity high. These conditions have favored the formation of peat and a large number of wetlands and lakes. The páramo usually presents deep and organicrich soils. In Colombia, the Andes branch into three mountain ranges in which there are differentiated páramo complexes (Figure 1) above $3000 \mathrm{~m}$ altitude. The three mountain ranges show different amounts of precipitation (1000-4500 $\mathrm{mm}$ ) [2]. The largest area of páramo ecosystems in Colombia (70\%) is in the Eastern Cordillera followed by the Central Cordillera [3]. The Western Cordillera is much lower in altitude and, therefore, holds fewer complexes. Tertiary and Quaternary sedimentary rocks characterize the Eastern Cordillera, while the Central combines not only sedimentary material but also plutonic rocks and a history of high volcanism [4]. Paramo vegetation is dominated by grasses (Festuca and 
Calamagrostis spp.) and rosette plants of the Asteraceae family (Espeletia spp.), which are missing from the central and southern Andes [5]. Páramo complexes are "sky islands" of the northern Andes and host endemic biodiversity [6]. Despite their extraordinary natural and societal relevance, there has been limited research on Colombian páramo lakes.

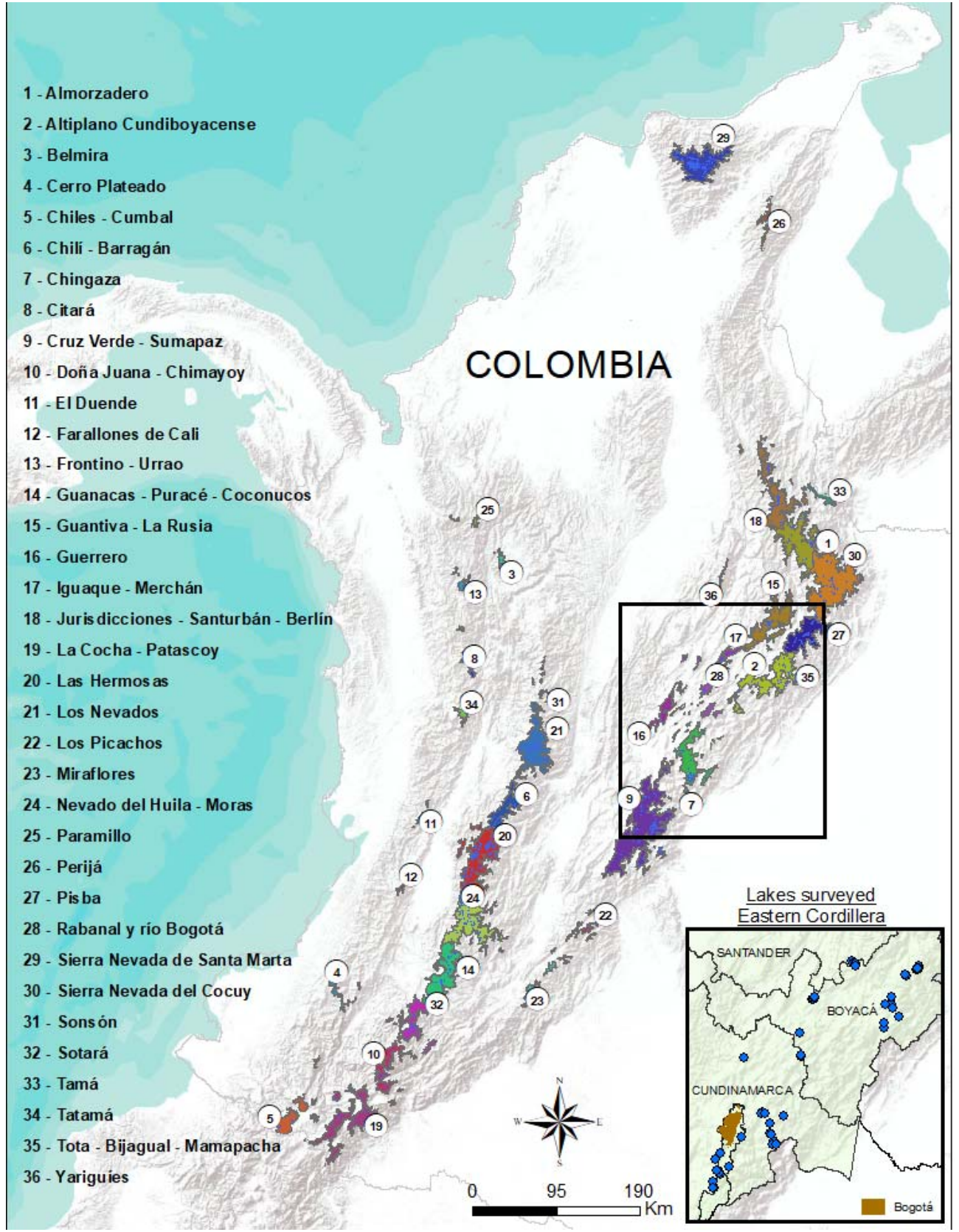

Figure 1. Distribution of páramo complexes in Colombia. Adapted from Instituto de Investigación de Recursos Biológicos Alexander von Humboldt $(2013,2021)$. The box shows the distribution of the lakes sampled for the physical and chemical study.

Existing studies have primarily focused on descriptions of the aquatic biota and relationships with the environment e.g., [7-10]. Very few studies have analyzed functional aspects such as primary production and trophic food webs [11-14]. However, extensive surveys of the assessment of the general limnological characteristics of these lakes are missing. Such studies are required to develop a reference framework for conserving the natural heritage and evaluating global change pressures, including climate shift, atmo- 
spheric pollution, and landscape fragmentation [15]. In the present study, we aim to cover the gap by making an inventory of the Colombian páramo lakes and characterizing the water chemistry based on a survey of lakes in the Eastern Cordillera.

The Eastern Cordillera holds the greatest páramo extension in Colombia, although it is also the one with the highest human landscape transformation, between $49 \%$ and $74 \%$ in some areas during the last two centuries $[3,16]$. Potato crops and livestock are the two activities that historically had the greatest impact on the páramo ecosystems [17], resulting in a significant landscape fragmentation [3]. Compared to the temperate zone, the tropical high-mountain sustains more population, and, thus, some parts have been submitted to local human pressures for centuries. Páramo ecosystems store a significant amount of carbon in their vegetation and soils [18], offering two key services in the current climate change scenario; carbon sequestration and water regulation. Since they are sensitive to disturbances, an understanding of the natural variability of their aquatic ecosystems could have significant implications for land management decisions.

The protection of páramo areas in Colombia is relatively recent, mostly occurring in the late 1970s. There are still many lakes outside protected areas and, even in them, many watersheds have had some degree of intervention in the last 50 years. Therefore, we considered lakes both in protected and non-protected areas in our survey and planned to discuss whether protection measures are sufficient at present and which are the main threats under ongoing global change [19]. On the other hand, this work provides a baseline of the physical and chemical characteristics of these high mountain lakes. This information, in addition to being a reference point for monitoring in the scenario of global change, will allow the identification of páramo complexes that deserve greater attention in the definition of management policies and ecosystems that have a high value for their conservation.

\section{Methods}

\subsection{Distribution of Colombian High-Mountain Lakes}

The Colombian high-mountain lakes are clustered in isolated páramo complexes distributed across the mountain ranges and covering 2,900,000 $\mathrm{km}^{2}$ (Figure 1). Using available 30-m resolution digital maps [20-23], we extracted layers of páramo complexes, protected areas, and lakes and intersected them to obtain lake inventories and statistics for each páramo complex. ArcGIS ${ }^{\circledR}$ software by Esri (Redlands, CA, USA) was used to perform all cartographic spatial analyses.

\subsection{Eastern Cordillera Sampling and Analyses}

The Eastern Cordillera extends between approximately $1^{\circ} 05^{\prime}$ and $8^{\circ} 40^{\prime} \mathrm{N}$ and is predominantly tectonic in origin [24]. The lithology predominantly dates back to Cretaceous and Eocene periods, consisting of sedimentary rocks of continental or transitional marine-continental origin, with some Jurassic plutonic rocks and Quaternary modeling at high altitudes [25]. We sampled 51 lakes at the Eastern Cordillera $>0.3$ ha and above $3000 \mathrm{~m}$ a.s.l., selected to cover variation across altitude, geology, protection level, and land use. The lake survey was performed during the drought period (between January and March 2017), when radiation is the highest, and the effect of dilution of ions and nutrients caused by rainfall is reduced. The selected lakes were mainly located in areas with current protection status $(86 \%)$. There is no detailed information on land use in the lake basins, but field observations indicate that among the lakes with protection status, $35 \%$ present some type of current or very recent affectation (dams, introduced trout, presence of cattle, and vestiges of agriculture in the basin).

Lake depth was measured using an acoustic probe and GPS in points evenly distributed in each lake. A minimum of 30 points was measured in the smaller lakes $(<1 \mathrm{ha})$ and at least 100 points in the larger ones. The lake bathymetry was obtained using kriging interpolation. Lake area was calculated from orthophoto maps and total volume by trapezoidal integration of sections: 0.2-m layers for lakes with depth $<2 \mathrm{~m}, 0.5-\mathrm{m}$ for $5 \mathrm{~m}$ depth, and 1-m for the deepest lakes. 
The transparency of the water was measured using the Secchi disk depth (SD) and a photic index calculated as the ratio between the photic zone depth (i.e., $\mathrm{SD} \times 2.3$ ) and the maximum depth $\left(Z_{\max }\right)$. Vertical profiles of temperature and oxygen were performed, and surface water was sampled in the central area of the lake for chemical analyses of alkalinity, $\mathrm{Ca}^{2+}, \mathrm{Mg}^{2+}, \mathrm{Mn}^{2+}, \mathrm{Na}^{+}, \mathrm{K}^{+}, \mathrm{Cl}^{-}$, total phosphorus (TP), $\mathrm{SO}_{4}{ }^{2-}, \mathrm{PO}_{4}{ }^{3-}$, total organic carbon (TOC), total Kjeldahl nitrogen (TKN), $\mathrm{NH}_{4}{ }^{+}, \mathrm{NO}_{3}{ }^{-}, \mathrm{NO}_{2}{ }^{-}$, and $\mathrm{SiO}_{2}$. Chemical analyses were performed following standard methods for the examination of water and wastewater [26]. The main environmental gradients were assessed by principal component analysis (PCA). The environmental variables were transformed using $\log _{10}$ or square root. Temperature, altitude and $\mathrm{pH}$ were not transformed because they already had a central distribution. PCA is an ordination technique that arranges environmental variables and samples in a space with a reduced number of dimensions. The PCA allows analysis of environmental gradients, correlations between variables and the distribution of the samples with respect to the set of gradients of all the variables. The set of variables that has a greater weight in one of the dimensions (axes) can be interpreted together as a response to a latent factor.

\section{Results}

\subsection{Distribution of Páramo Lakes}

The analysis of digital maps showed that there are 3250 lakes in 28 out of 36 Colombian páramo complexes (Table 1), with $71 \%$ in protected areas. The highest number occurs in the Eastern Cordillera (44\%), 39.6\% in the Central Cordillera, and $13.7 \%$ in the Sierra Nevada de Santa Marta. The highest density of lakes occurs in Los Nevados, Sierra Nevada de Santa Marta, Las Hermosas, and Pisba complexes 0.003, 0.0029, 0.0025, and 0.0025 lakes ha ${ }^{-1}$, respectively).

The lake's altitude ranges from 3000 to 5100 m.a.s.l., showing a bimodal distribution, with a primary mode at $3700 \mathrm{~m}$ and a secondary at $4300 \mathrm{~m}$ (Figure 2). The highest mode corresponds mainly to the Cocuy, Sierra Nevada de Santa Marta, and Los Nevados complexes.

Lake area ranges between 0.005 and 217 ha (Figure 2). The distribution is unimodal, with the mode slightly lower than 1 ha. The largest lakes mainly occur in three páramo complexes, Chiles-Cumbal, Sotará, and Cocuy.

\subsection{Characteristics of Eastern Cordillera Lakes}

The altitudinal distribution of the lakes surveyed in the Eastern Cordillera followed the primary mode of the whole set of páramo lakes (Figure 3), whereas the lake area showed a larger median $(\sim 2 \mathrm{ha})$, with centered distribution and a tail of a few large lakes (Table 2, Figure 3). There is no spatial pattern in the distribution of lakes according to altitude or area (Figure 4). Maximum depth was usually $<10 \mathrm{~m}$, only few lakes showed $>20 \mathrm{~m}$. Likewise, the mean depth was low (median $<2 \mathrm{~m}$ ). Consequently, the lake volume was relatively small compared to the lake surface. Morphometry differences between páramo complexes were irrelevant, except in the Sumapaz complex, where the lakes were exceptionally shallow (Figure 4). 
Table 1. Páramo complexes of Colombia and lake distribution. C: Cordillera.

\begin{tabular}{|c|c|c|c|c|c|c|c|c|}
\hline ID & Páramo Complex & Sector & $\begin{array}{l}\text { Total Páramo } \\
\text { Area (ha) }\end{array}$ & $\begin{array}{c}\text { Protected } \\
\text { Fraction (\%) }\end{array}$ & $\begin{array}{c}\text { Protection under National } \\
\text { Park System (\%) }\end{array}$ & $\begin{array}{l}\text { Number } \\
\text { of Lakes }\end{array}$ & $\begin{array}{c}\text { Number of Lakes in } \\
\text { Protected Areas }\end{array}$ & $\begin{array}{l}\text { Area Covered by } \\
\text { Lakes (ha) }\end{array}$ \\
\hline 1 & Almorzadero & Eastern C. & 156,552 & 0.4 & & 128 & & 301 \\
\hline 2 & Altiplano Cundiboyacense & Eastern C. & 4657 & 4 & & & & \\
\hline 3 & Belmira & Western C. & 10,622 & $\stackrel{+}{100}$ & & 1 & 1 & 0.3 \\
\hline 5 & Chiles-Cumbal & Nariño-Putumayo & 63,223 & 15 & & 3 & & 247 \\
\hline 6 & Chilí-Barragán & Central C. & 80,708 & 29 & & 78 & 11 & 267 \\
\hline 7 & Chingaza & Eastern C. & 109,956 & 73 & 44 & 124 & 103 & 245 \\
\hline 8 & Citará & Western C. & 11,233 & 56 & & 1 & 1 & 2 \\
\hline 9 & Cruz Verde-Sumapaz & Eastern C. & 333,420 & 52 & 42 & 324 & 220 & 1095 \\
\hline 11 & El Duende & Western C. & 4454 & 34 & & & & \\
\hline 12 & Farallones de Cali & Western C. & 4545 & 100 & 100 & & & \\
\hline 13 & Frontino-Urrao & Western C. & 13,921 & 85 & 8 & 2 & 2 & 7 \\
\hline 14 & Guanacas-Puracé-Coconucos & Central C. & 137,677 & 23 & 23 & 81 & 39 & 285 \\
\hline 15 & Guantiva-La Rusia & Eastern C. & 119,750 & 45 & 3 & 92 & 88 & 139 \\
\hline 16 & Guerrero & Eastern C. & 42,325 & 75 & $J$ & 71 & 51 & 65 \\
\hline 17 & Iguaque-Merchán & Eastern C. & 28,311 & 46 & 18 & 15 & 12 & 17 \\
\hline 18 & Santurbán-Berlín & Eastern C. & 142,608 & 35 & & 207 & 92 & 290 \\
\hline 19 & La Cocha-Patascoy & Nariño-Putumavo & 145,539 & 35 & 4 & 50 & 28 & 179 \\
\hline 20 & Las Hermosas & Central C. & 208,011 & 64 & 55 & 526 & 429 & 1437 \\
\hline 21 & Los Nevados & Central C. & 146,027 & 49 & 39 & 438 & 395 & 373 \\
\hline 24 & Nevado del Huila-Moras & Central C. & 150,538 & 78 & 77 & 149 & 96 & 465 \\
\hline 25 & Paramillo & Western C. & 6744 & 100 & 100 & 2 & 2 & 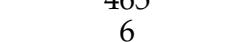 \\
\hline 26 & Perijá & Eastern C. & 29,727 & 81 & & 1 & & 0.1 \\
\hline 27 & Pisba & Eastern C. & 106,243 & 27 & 27 & 265 & 140 & 253 \\
\hline 28 & Rabanal v río Bogotá & Eastern C. & 24,650 & 66 & & 3 & 3 & 7 \\
\hline 29 & Sierra Nevada de Santa Marta & Sierra Nevada & 151,021 & 95 & 95 & 445 & 445 & 1600 \\
\hline 30 & Sierra Nevada del Cocuy & Eastern C. & 271,033 & 65 & 65 & 78 & 47 & 576 \\
\hline 31 & Sonsón & Central C. & 8707 & 40 & & & & \\
\hline 32 & Sotará & Central C. & 80,929 & 38 & 31 & 15 & 12 & 146 \\
\hline 33 & Tamá & Eastern C. & 16,339 & 75 & 53 & 2 & & 3 \\
\hline 34 & Tatamá & Western C. & 10,930 & 100 & 100 & & & \\
\hline 35 & Tota-Bijagual-Mamapacha & Eastern C. & 151,498 & 47 & & 120 & 73 & 208 \\
\hline \multirow{2}{*}{$\begin{array}{l}35 \\
36\end{array}$} & $\begin{array}{l}\text { Yariguíes } \\
\text { You }\end{array}$ & Eastern C. & 4252 & $\begin{array}{l}47 \\
99\end{array}$ & 96 & & & \\
\hline & Total & & $2,906,137$ & 50.8 & 33.3 & 3250 & 2303 & 8281 \\
\hline
\end{tabular}



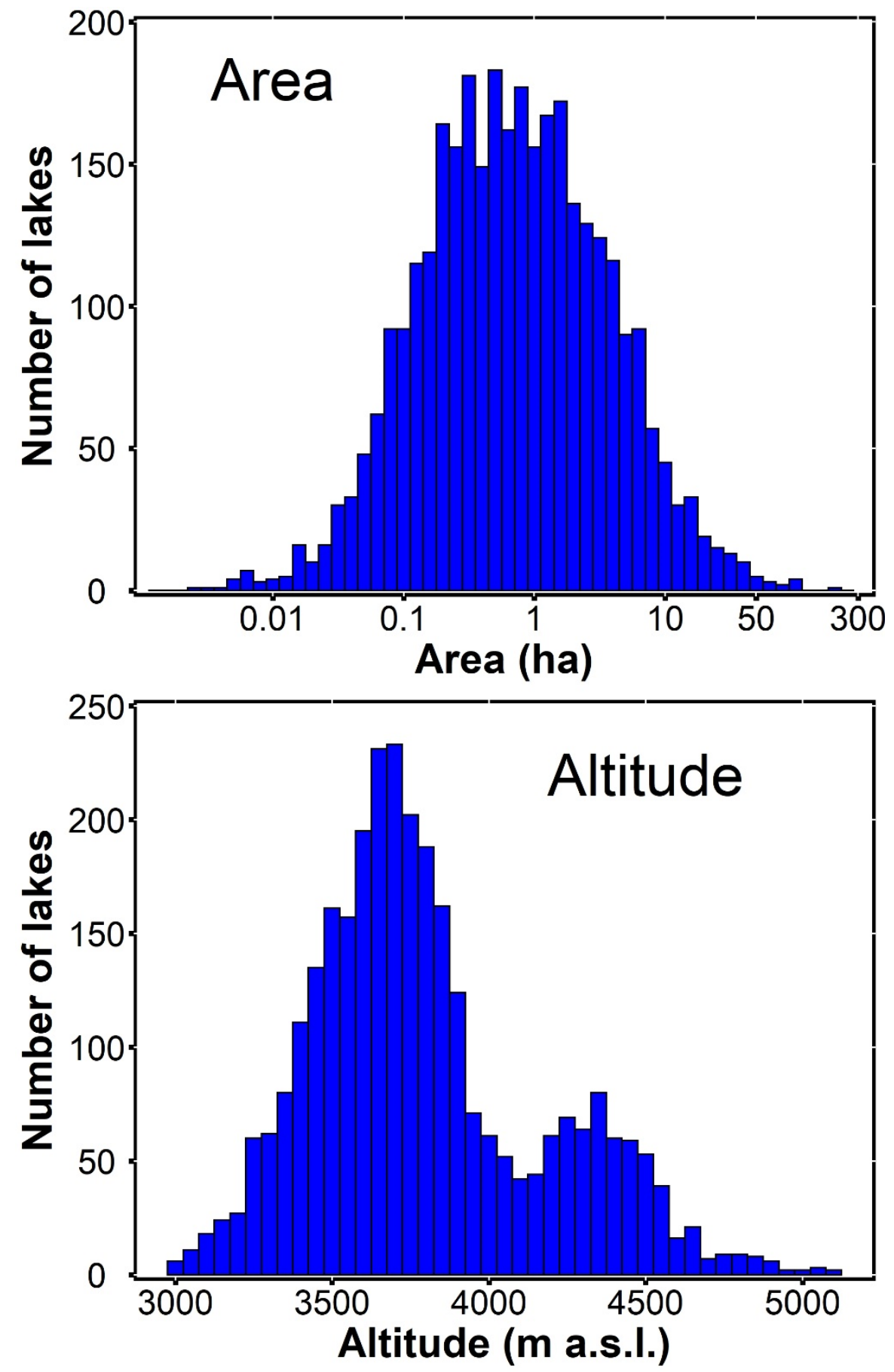

Figure 2. Area and altitude distributions of the Colombian páramo lakes.

Water transparency was low (average SD $3.5 \mathrm{~m}$ ). However, the photic zone extended to bottom in $65 \%$ of the lakes because of the shallowness (Table 2). The lakes located in the northern zone of the survey (Pisba and Guantiva-Russia páramos) showed the highest water transparency (Figure 4).

Surface water temperature was usually $<15^{\circ} \mathrm{C}$. The average temperature difference between surface and bottom was $1.2{ }^{\circ} \mathrm{C}$, but in the deepest lakes, it reached up to $4{ }^{\circ} \mathrm{C}$. The oxygen saturation was high at surface $(>78 \%)$ but highly variable at bottom, ranging from oversaturation to anoxia (Table 2). 
Table 2. Summary of the morphometrical and chemical characteristics of 51 páramo lakes in the Eastern Cordillera of the Colombian Andes.

\begin{tabular}{|c|c|c|c|c|c|}
\hline Variable & Minimum & Maximum & Median & Mean & $\begin{array}{l}\text { Coefficient } \\
\text { of Variation }\end{array}$ \\
\hline Altitude (m a.s.l.) & 3014 & 3830 & 3612 & 3580 & 0.05 \\
\hline Area (ha) & 0.3 & 104.8 & 2.5 & 6.3 & 2.45 \\
\hline Maximum length (m) & 77 & 1781 & 245 & 343 & 0.82 \\
\hline Volume $\left(\times 10^{3} \mathrm{~m}^{3}\right)$ & 1.0 & 13,303 & 38.6 & 438.6 & 4.28 \\
\hline $\mathrm{Z}_{\max }(\mathrm{m})$ & 0.4 & 44.3 & 6.3 & 8.2 & 0.97 \\
\hline $\mathrm{Z}_{\text {mean }}(\mathrm{m})$ & 0.1 & 17.0 & 1.8 & 2.8 & 1.18 \\
\hline Secchi disk (m) & 0.3 & 8.4 & 3.2 & 3.5 & 0.64 \\
\hline Photic index & 0.29 & 2.35 & 1.63 & 1.39 & 0.49 \\
\hline Conductivity $(\mu \mathrm{S} / \mathrm{cm})$ & 2.0 & 72.0 & 5.0 & 10.7 & 1.26 \\
\hline Surface temperature $\left({ }^{\circ} \mathrm{C}\right)$ & 9.4 & 18.8 & 12.1 & 12.5 & 0.15 \\
\hline Vertical temperature gradient $\left({ }^{\circ} \mathrm{C}\right)$ & 0 & 4.2 & 1 & 1.21 & 0.94 \\
\hline $\mathrm{O}_{2}$ at surface $(\mathrm{mg} / \mathrm{L})$ & 5 & 8.2 & 6.52 & 6.72 & 0.10 \\
\hline $\mathrm{O}_{2}$ at bottom $(\mathrm{mg} / \mathrm{L})$ & 0 & 6.9 & 4.08 & 3.49 & 0.73 \\
\hline $\mathrm{O}_{2}$ saturation at surface $(\%)$ & 78 & 117.1 & 99.9 & 99.0 & 0.10 \\
\hline $\mathrm{O}_{2}$ saturation at bottom $(\%)$ & 0 & 110.6 & 56.6 & 50.5 & 0.74 \\
\hline $\mathrm{pH}$ & 4.7 & 8.0 & 6.1 & 6.1 & 0.16 \\
\hline Alkalinity ( $\mu \mathrm{eq} / \mathrm{L} \mathrm{CaCO}_{3}$ ) & 6 & 848 & 30 & 100 & 1.56 \\
\hline $\mathrm{SO}_{4}^{2-}(\mathrm{mg} / \mathrm{L})$ & 0.003 & 44.1 & 0.003 & 1.322 & 4.67 \\
\hline $\mathrm{Ca}^{2+}(\mathrm{mg} / \mathrm{L})$ & 0.17 & 7.82 & 0.62 & 1.38 & 1.38 \\
\hline $\mathrm{Mg}^{2+}(\mathrm{mg} / \mathrm{L})$ & 0.04 & 1.11 & 0.16 & 0.26 & 0.97 \\
\hline $\mathrm{Na}^{+}(\mathrm{mg} / \mathrm{L})$ & 0.37 & 1.73 & 0.66 & 0.73 & 0.33 \\
\hline $\mathrm{Mn}^{2+}(\mathrm{mg} / \mathrm{L})$ & 0.00 & 0.09 & 0.01 & 0.02 & 0.88 \\
\hline $\mathrm{K}^{+}(\mathrm{mg} / \mathrm{L})$ & 0.03 & 0.86 & 0.12 & 0.14 & 0.94 \\
\hline Total Fe $(\mathrm{mg} / \mathrm{L})$ & 0.04 & 2.20 & 0.21 & 0.32 & 1.09 \\
\hline $\mathrm{Cl}^{-}(\mathrm{mg} / \mathrm{L})$ & 0.03 & 3.73 & 0.18 & 0.34 & 2.03 \\
\hline Total organic carbon $(\mathrm{mg} / \mathrm{L})$ & 2.6 & 14.0 & 6.2 & 6.3 & 0.40 \\
\hline Total Kjeldahl nitrogen (mg/L) & 0.70 & 1.40 & 0.98 & 1.01 & 0.17 \\
\hline $\mathrm{NH}_{4}^{+}(\mathrm{mg} / \mathrm{L})$ & 0.28 & 0.84 & 0.42 & 0.51 & 0.36 \\
\hline $\mathrm{NO}_{3}-(\mathrm{mg} / \mathrm{L})$ & 0.001 & 0.179 & 0.007 & 0.016 & 1.83 \\
\hline Total phosphorus (mg/L) & 0.02 & 2.05 & 0.40 & 0.55 & 0.79 \\
\hline $\mathrm{PO}_{4}{ }^{3-}(\mathrm{mg} / \mathrm{L})$ & 0.003 & 1.125 & 0.014 & 0.164 & 1.77 \\
\hline $\mathrm{Si}(\mathrm{mg} / \mathrm{L})$ & 0.13 & 3.75 & 1.20 & 1.37 & 0.62 \\
\hline
\end{tabular}

Alkalinity was low in most lakes $(<200 \mu \mathrm{eq} / \mathrm{L})$, except in a few with values $\sim 1 \mathrm{meq} / \mathrm{L}$. The dominant cation was $\mathrm{Ca}^{2+}$ but with relatively low values (Table 2). Consequently, lake waters showed low buffering capacity, and $\mathrm{pH}$ was commonly well below 7 , but with only a few cases of extremely low values $(<5)$. Total organic carbon was generally relatively high $(\sim 6 \mathrm{mg} / \mathrm{L})$, although it did not correlate significantly with water acidity. TOC did not show a spatial pattern (Figure 4 ).

Nitrogen concentration was low. The largely dominant dissolved inorganic form was $\mathrm{NH}_{4}{ }^{+}$(Table 2), usually accounting for more than $50 \%$ of the TKN. TP and $\mathrm{PO}_{4}{ }^{3-}$ concentrations were high in most of the investigated complexes, indicating general mesotrophic and eutrophic conditions, with a few hypereutrophic exceptions. TP presented higher values in the páramos of the southern area sampled (Cruz Verde-Sumapaz and Chingaza).

The PCA summarized two latent factors of similar contribution to the water characteristics (Figure 5). One of the factors related to bedrock geology, which provides the major water chemicals and buffering capacity (i.e., $\mathrm{pH}$, alkalinity, $\mathrm{Ca}^{2+}, \mathrm{Mg}^{2+}$, and $\mathrm{SO}_{4}{ }^{2-}$ ). The second factor encompassed many variables defining the trophic state. Phosphorus variables showed the highest contribution to this factor. Variation in both factors was relatively high in every páramo complex. Lakes in Pisba and Guantiva-La Rusia were less productive and tended to hold softer waters; Tota-Rabanal, the hardest waters; and Sumapaz and Guerrero were he lakes of the highest trophic state. 

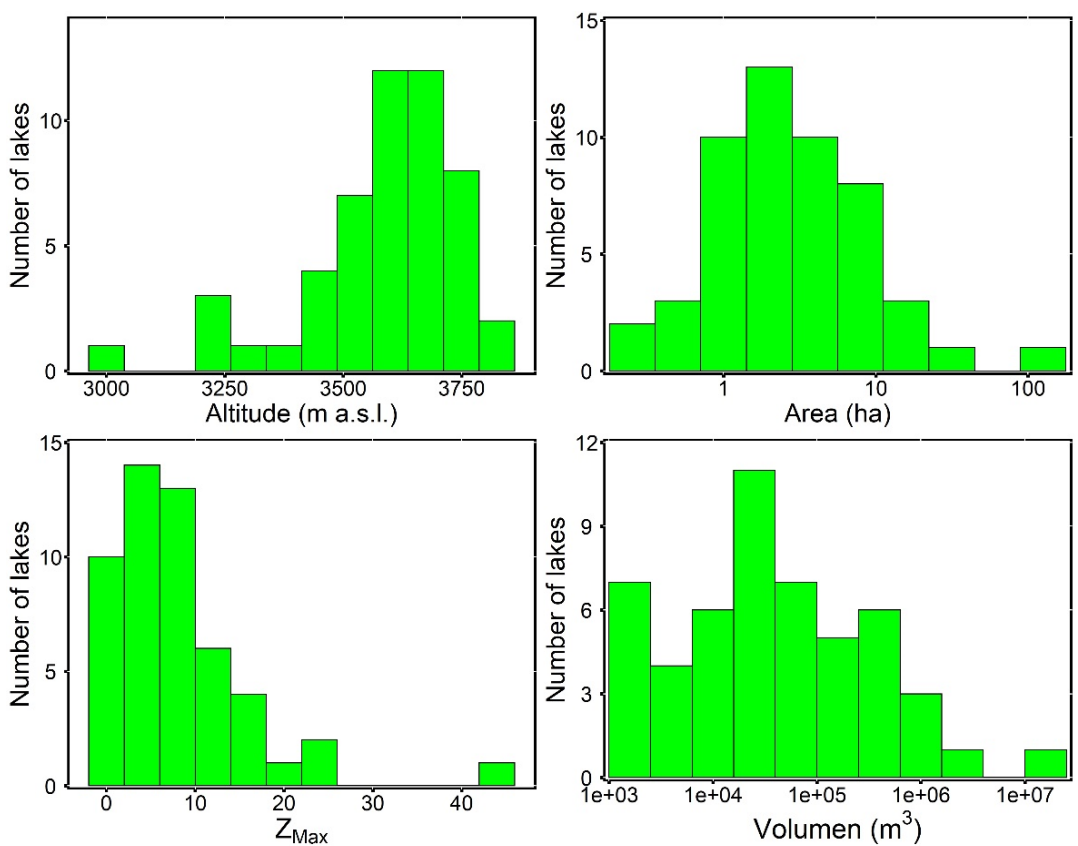

Figure 3. Morphometry of the 51 lakes studied in the Eastern Cordillera of the Colombian Andes.

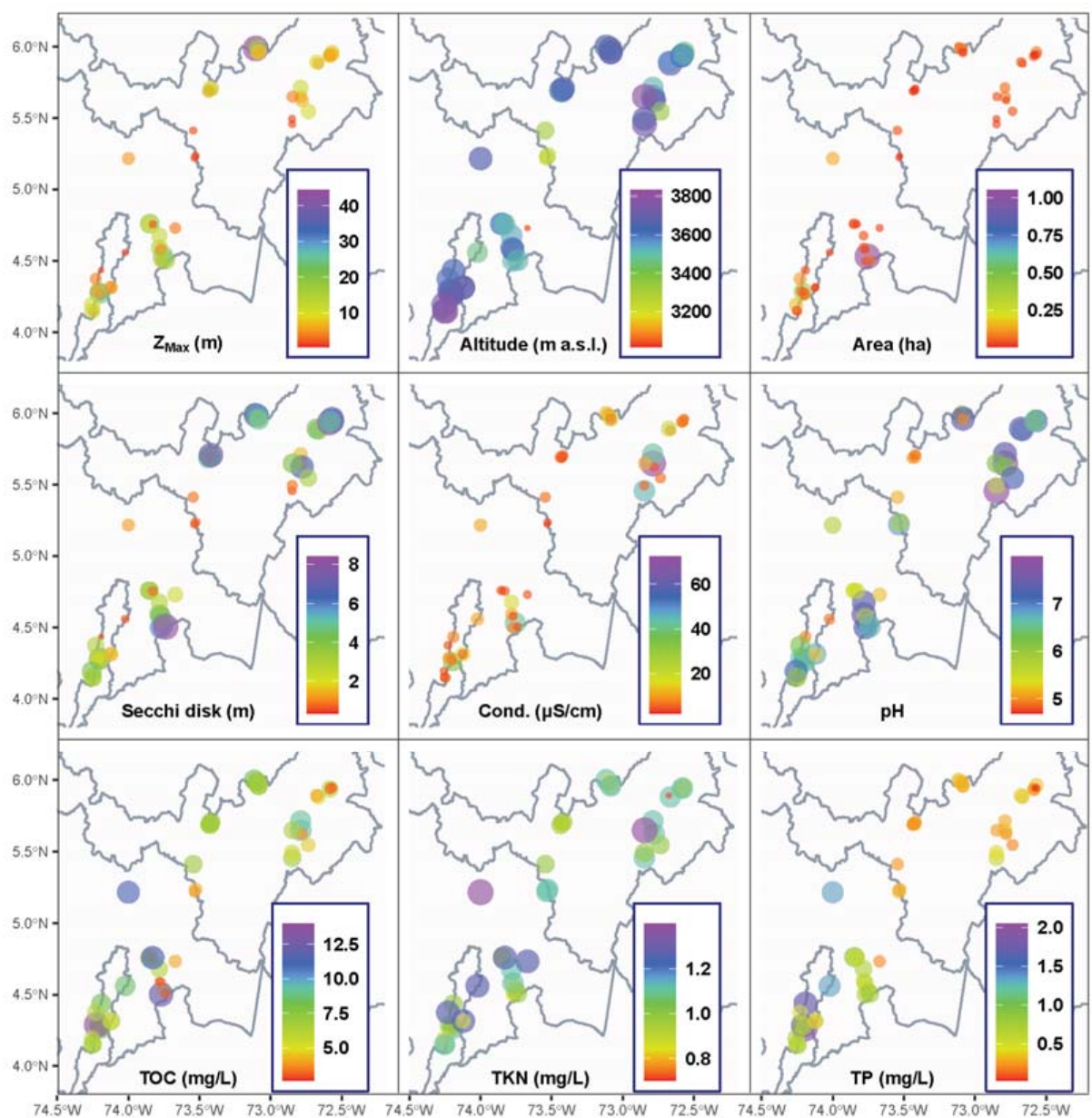

Figure 4. Spatial variation of geographical, geomorphological, physical and chemical variables of the 51 lakes sampled. 

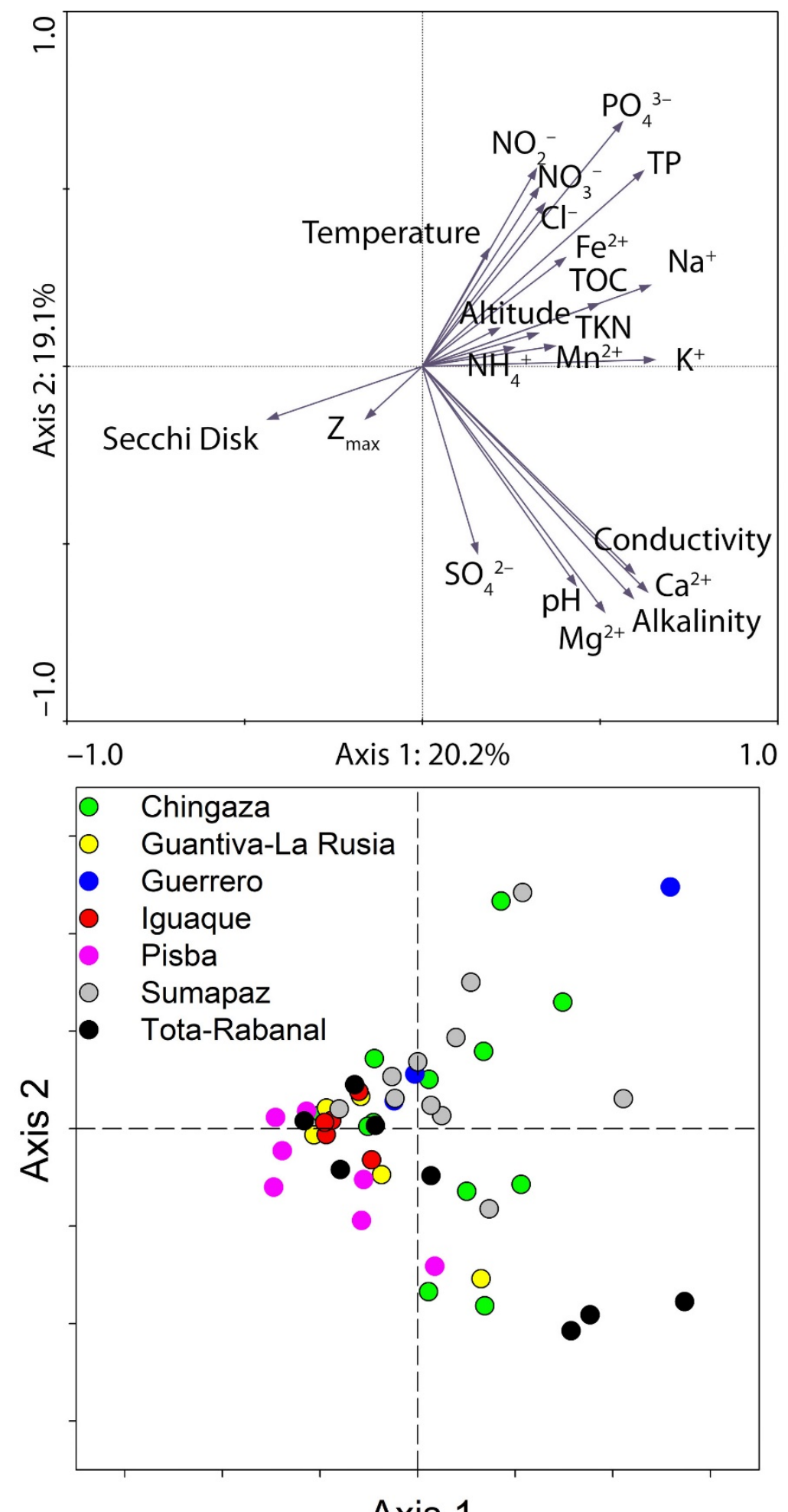

Figure 5. Biplot of the principal component analyses of selected environmental variables. The upper figure presents the relationship between the environmental variables. The direction of the arrows indicates the direction of the gradient and the position of samples with the highest values of each variable. The closer the arrows, the more correlated are the environmental variables. The second figure shows the position of each lake with respect to the environmental variables. The colors of the lakes correspond to the different páramo complexes studied. 


\section{Discussion}

\subsection{Distribution of Páramo Lakes}

The altitudinal distribution of páramo lakes responds to the glacial modeling of the Andes of Colombia. During the last glacial maximum, glaciers reached $4300 \mathrm{~m}$ a.s.l. [27,28], whereas the formation of lake basins at lower altitudes can be traced back to older cold periods [29]. These dual erosive glacial phases could be the explanation for the bimodal lake distribution found. The páramo complexes, where glaciers still exist today, are the ones with lakes at the higher altitudes, suggesting a more recent basin formation. These lakes show small and silted basins. Nonetheless, there is no significant general relationship between altitude and lake number or size.

The complexes of Las Hermosas, Sierra Nevada de Santa Marta, and Los Nevados are of greater interest from the conservation perspective because of the higher number of lakes than in other complexes and the large proportion with protection status. In contrast, a small number of lakes are part of protected areas in the complexes of Cruz Verde-Sumapaz, Santurbán, and Pisba.

\subsection{Eastern Cordillera Lake Characteristics}

Generally, glacier modeling in temperate mountain regions has caused relatively deep basins compared to the lake area, in contrast to ice modeling in subarctic areas [30]. The average depth of lakes in the Pyrenees is around 15-20 m [31]. Lakes in the Andean equatorial region tend to show lower average depth, e.g., around $10 \mathrm{~m}$ in the Cajas massive in Southern Ecuador [32]. Existing information indicates that the lake aspect ratio for the Colombian Andes tends to be closer to subarctic lakes than those of the temperate zone [15]. Our survey confirms this tendency. The reason may be related to an erosive process in a more open high-mountain landscape than in other ranges with narrower valleys.

Unlike most alpine high-mountain watersheds, the páramo is covered by dense shrubby vegetation [33]. High air humidity throughout most of the year and average temperature values between $3-13{ }^{\circ} \mathrm{C}[34,35]$ promote extensive marsh vegetation around the lakes, which are limited by an extensive belt of terrestrial-aquatic transition zone [35]. Consequently, the organic matter load is potentially high, explaining the consistently high TOC values in the lakes studied [36,37]. This feature also makes the páramo lakes more similar to tundra lakes than temperate alpine lakes.

The Secchi disk values indicated that the transparency of the studied lakes in the Eastern Cordillera is very low compared to that in the temperate zone $[30,38]$ and mountain lakes from Southern Ecuador [37]. However, despite the low water transparency, the light penetration is sufficient for macrophyte and algal growth at the bottom of most of the lakes due to the shallowness. This fact has major implications for the ecosystem as it increases the lake's primary productivity $[39,40]$.

The investigated lakes showed $\mathrm{pH}$ values mainly in the acidic range, with low buffer capacity because of the low cation concentration [41]. TOC and $\mathrm{pH}$ were not correlated $(r=0.1, p=0.5, n=60)$, indicating a low contribution of organic acids to acidity, which was primarily related to the inorganic ionic balance. All in all, the high diversity in TOC concentration among lakes merits further investigation about the TOC specific nature and the process determining its levels.

Total nitrogen and phosphorus levels were significantly higher than those reported for high-mountain lakes in other areas of the world [42,43]. Ammonium accumulation at levels above nitrate is particularly remarkable, which may point to some limitations for nitrification or a continuous flux from deep layers and sediments. This issue, and the nitrogen cycle as a whole, considering atmospheric deposition, watershed loadings, and fixation, deserve further research in these lakes [44].

The proportion of $\mathrm{PO}_{4}{ }^{3-}$ respective to TP fluctuates strongly but is remarkably high $(>20 \%)$ in many lakes. This feature and the relatively high nitrogen levels points to a light limitation in some of these lakes. Thus, there is a significant relationship between the ratio $\mathrm{PO}_{4}{ }^{3-} / \mathrm{TP}$ and the TOC $(r=0.32, p=0.02, n=51)$. In any case, TP is high, indicating 
mesotrophic to eutrophic conditions, in contrast to the usual oligotrophic character of highmountain lakes [10]. On the one hand, the relatively low oxygen values at the bottom may facilitate phosphorus diffusion from recycling in the sediments [45]. On the other hand, the shallowness of the lakes fosters the relevance of the littoral and bottom primary producers and the influence of thycoplankton in open waters $[46,47]$. Although the characteristics pointed here refer to the páramo lakes of the Eastern Cordillera, there is no reason to expect that they will not apply to the whole set of páramo lakes in Colombia.

\subsection{Páramo Lakes in the Context of Global Change}

The main factors associated with global change that could affect the páramo lakes are the increase in air temperature, changes in the rainfall regime, changes in land use, and atmospheric transport of pollutants. These processes have been widely documented in remote mountain lakes [48-50]. The potential impacts of these processes range from in-lake moderate changes (e.g., water column stability, oxygen demand) to large watershed and external loading modifications (e.g., water level, organic loads, pollutant accumulation), eventually leading to marked changes in communities and food webs (Figure 6).

\section{Global Environmental Change processes}

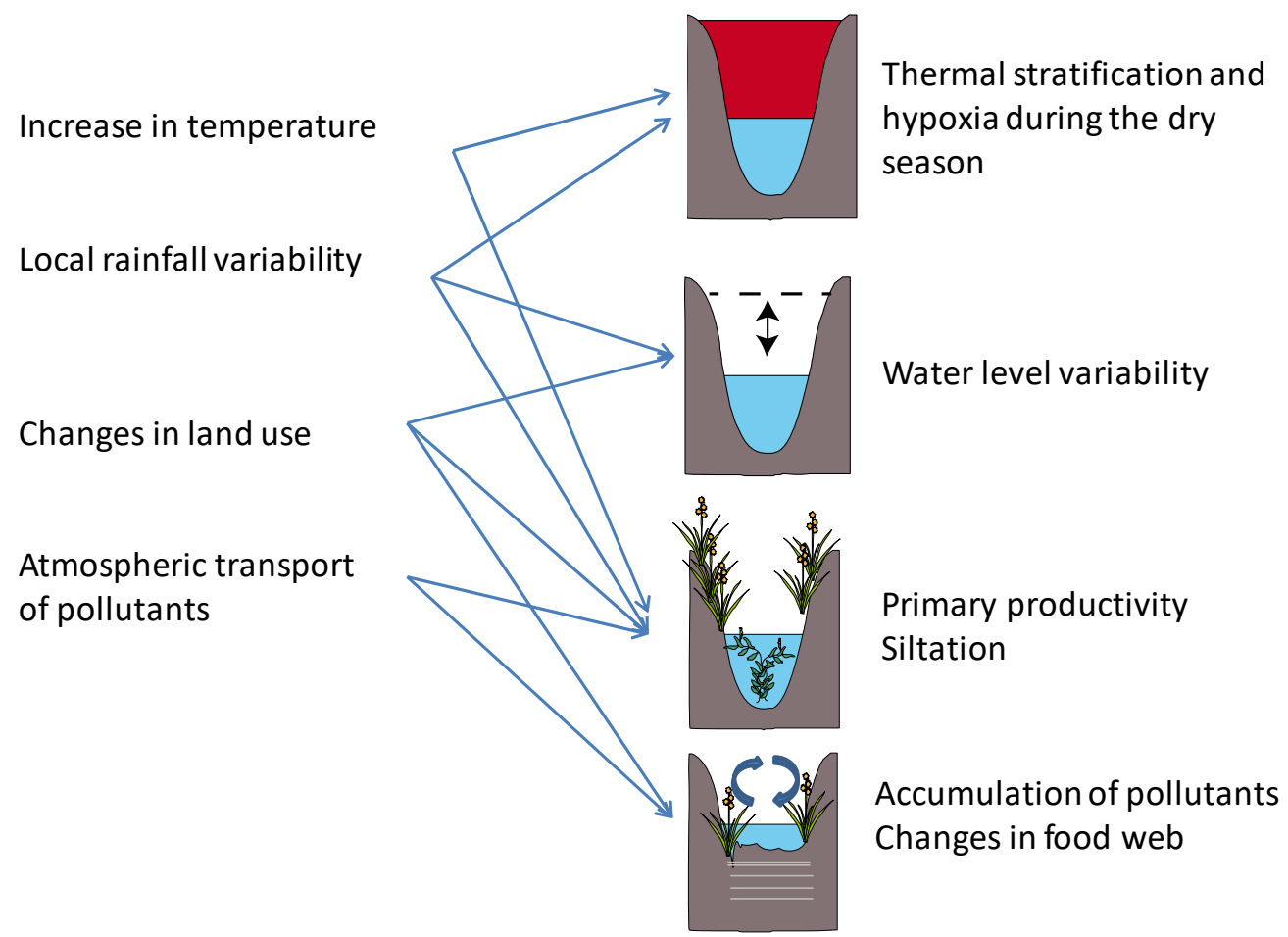

\section{Páramo lakes processes potentially impacted}

Thermal stratification and hypoxia during the dry season

Primary productivity Siltation
Figure 6. Conceptual sketch of the potential effects of global change on páramo lakes (Arrows indicate drivers (left) enhancement of the processes (right).

Studies have projected an increase in air temperature of between 3 and $4{ }^{\circ} \mathrm{C}$ in the Andes high mountains [51], resulting in some of these lakes possibly exceeding $20^{\circ} \mathrm{C}$ during periods of high radiation. Higher temperatures will accelerate organism metabolism and, consequently, biogeochemical processes. Respiration is more sensitive than photosynthesis to temperature, but higher recycling may result in a higher trophic state of the lakes [52]. Higher biomass and metabolism will increase oxygen demand [53], and warmer waters and stronger stratification may limit the supply [54]; thus, the lakes may become more similar to tropical lakes of lower altitudes [55]. Oxygen values in hypolimnion already tend to be low in the lakes studied, so an increase in hypoxia will enhance phosphorus 
mobilization. Lakes that currently have the highest phosphorus values could experience significant water quality deterioration in the coming decades. This is the case of lakes near the main urban centers of Colombia. These systems, due to their proximity to the city of Bogotá, presented a history of high affectation during the last two centuries and, therefore, could have a low capacity to mitigate the impact of the increase in temperature. On the other hand, during the dry season all these effects can be enhanced by substantially increasing the metabolism of the lakes. Since our study is based on a sampling carried out during the dry period, the chemical composition of the lakes in future scenarios, with longer periods of drought, could be similar to the more enriched lakes that were observed. During the rainy season, dilution could reduce the concentration of nutrients, but could increase the contribution of organic matter from the basin.

Climate change may also affect rainfall seasonality, with more extended and more frequent periods of drought expected [1]. Our results show that the lakes of the Eastern Cordillera are very shallow ecosystems, so that longer periods of drought will have a great impact. Even though there are a high number of small bodies of water, the shallow depth determines that the water storage capacity will be low. Aquatic plant communities, especially those that inhabit the terrestrial-aquatic transition and submerged macrophytes without rapid regeneration, will be quickly affected by these changes [56,57]. Most of the lakes studied showed a photic layer that reaches the sediment, so the reduction in depth could increase the role of algal productivity in the deeper lakes, while the shallower lakes could suffer a progressive invasion of littoral plants. More importantly, páramo peatlands may experience periods of high release of organic material to the lakes, enhancing lake metabolism and oxygen demand. The shifting conditions may last for long periods, and human land use in the watersheds may enhance the processes. The long-range transport of pollutants to these lakes, another component of global change, is largely unknown [15]. The lake watershed protection should reduce undesirable synergies between global change and local land use and provide better stewardship of any unavoidable shift produced by climate transitions [58].

\subsection{Páramo Lake Conservation}

The results of the lake chemical analyses did not show a pattern, from which it could be concluded that a low lake trophic state is related to protection status (Figure 7). Despite the imbalance in the number of lakes considered between conserved and non-conserved areas, the high variability and the high concentration of TP and TOC in lakes of some National Parks such as Chingaza and Sumapaz suggests that this result shows more the degree of affectation suffered by the different complexes than the current conservation status. The System of Protected Areas in Colombia is relatively recent. Páramo protection is mainly under the jurisdiction of the national park system (33\%), and smaller areas are managed by municipal or private regional reserves $(12 \%)$. The majority of the páramo ecosystems were declared protected in 1977 as part of the National Natural Parks System of Colombia (decree 2811-1974 of the Republic of Colombia, 1975). Many of these areas previously had agricultural, livestock, and mining activities. Currently, most of them still have some type of agricultural management with low impact, such as extensive livestock. Surveying the past is possible with paleolimnological techniques [59]. The study of lake sediments can evaluate the effectiveness of the watershed conservation status and define reference conditions to manage human land use and climate interaction (e.g., land erosion and siltation of the lakes).

Strategic planning should also consider increasing the protected areas. Páramo ecosystems are a unique natural heritage for biodiversity. Fish introduction is one of the leading food web alterations in high-mountain lakes worldwide [60], including trout in the Andean tropical lakes [61]. Protection should reduce trout spreading and other undesirable fish species. Furthermore, if climate change modifies water availability, hydrological interventions (e.g., building dams, diverting streams) could be a pressure that prevention and planning should anticipate. The results presented here constitute a baseline for the 
definition of the trophic status of the lakes and for their monitoring. The shallow depth and the high content of organic matter and nutrients of most ecosystems suggest that they are ecosystems that require specific actions even in protected areas. The total elimination of livestock, the control of the introduction of trout and the assessment of the real potential of some lakes to provide water to local communities are actions that should be implemented urgently. The regular measurement of the water transparency, TP, TKN and the oxygen concentration in the hypolimnion would allow a response from these ecosystems to these actions during the progression of climate change.

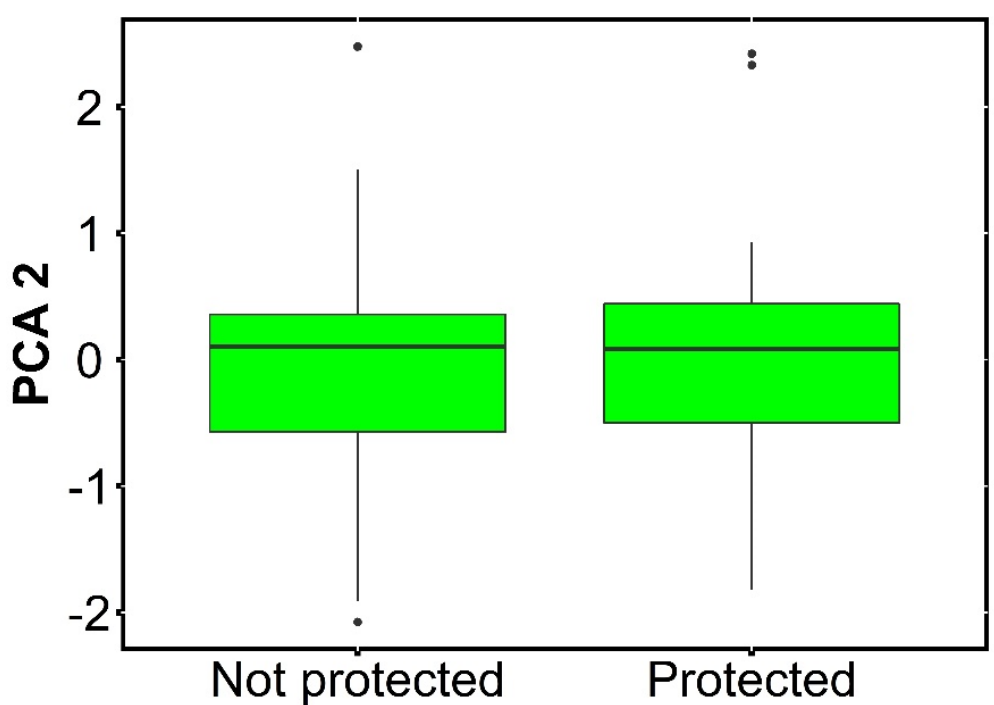

Figure 7. Boxplot of the second principal components (PCA 2) showed in Figure 5, grouping lakes by non-protected $(n=7)$ and protected areas $(n=44)$. Dots represent outliers.

\section{Conclusions}

The páramo lakes of Colombia are relatively small and fairly shallow lakes with limnological characteristics (e.g., low buffering capacity, high organic content, high nutrient concentration, and low oxygen) that make them extremely sensitive to local environmental pressures in their watersheds and during ongoing climate change. It becomes an urgent matter to increase the protected area and focus future research on assessing whether the current management of the watersheds is enough to guarantee a good ecological status and respond to challenging shifting global conditions.

Author Contributions: Conceptualization, C.A.R.-R., A.Z. and J.C.; methodology, A.Z., C.A.R.R.; D.V., C.L.M.-L. and M.M.-R.; data analysis: A.Z., C.A.R.-R.; D.V., C.L.M.-L., M.M.-R. and J.C.; writing-original draft preparation, A.Z., C.A.R.-R., D.V., C.L.M.-L. and M.M.-R.; writing-review and editing, A.Z., C.A.R.-R. and J.C. All authors have read and agreed to the published version of the manuscript.

Funding: This study was funded by Ministerio de Ciencia, Tecnología e Innovación of Colombia (Colciencias 50000-050-2016) and Pontificia Universidad Javeriana (IDPPTA 6789 and ID PPTA 7066). C. Muñoz-López was supported by a PhD scholarship MinCiencias Colciencias-Colfuturo (No. 779 2017-Regiones Boyacá).

Institutional Review Board Statement: Not applicable.

Informed Consent Statement: Not applicable.

Acknowledgments: Thanks to Parques Nacionales Naturales de Colombia (Resolución No. 141-241016) and to the staff of the PNN Chingaza, PNN Sumapaz, SFF Guanentá Alto Río Fonce, SFF lguaque, and PNN Pisba, for their invaluable help during the fieldwork. Thanks to the project fieldwork team: Y. Caleño, D. Castillo, M. Guerrero, J. Jimenez, and L. Garzón for their invaluable help exploring the mountains lakes. 
Conflicts of Interest: The authors declare no conflict of interest.

\section{References}

1. Herzog, S.; Martínez, R.; Jørgensen, P.; Tiessen, H. (Eds.) Climate Change and Biodiversity in the Tropical Andes; Inter-American Institute for Global Change Research (IAI); Scientific Committee on Problems of the Environment (SCOPE): Paris, France, 2011; p. 348.

2. Van der Hammen, T.; Otero, J. Los páramos: Archipiélagos terrestres en el norte d elos Andes. In Atlas de Páramos de Colombia; Morales, M., Otero, J., Van der Hammen, T., Torres, A., Cadena, C., Pedraza, C., Rodríguez, N., Franco, C., Betancourt, J.C., Olaya, E., et al., Eds.; Instituto de Investigación de Recursos Biológicos Alexander von Humboldt: Bogotá, Colombia, 2007 ; p. 208.

3. Cabrera, M.; Ramirez, W. (Eds.) Restauración Ecológica de los Páramos de Colombia: Transformación y Herramientas para su Conservación; Instituto de Investigación de Recursos Biológicos Alexander von Humboldt: Bogotá, Colombia, 2014; p. 296.

4. Gómez, J.; Montes, N.E. Mapa Geológico de Colombia 2020, Escala 1:1,000,000; Servicio Geológico Colombiano, 2 Hojas: Bogotá, Colombia, 2020; p. 2.

5. Rangel, J.; Pinto-Zárate, J. Colombian Páramo Vegetation Database (CPVD)-The database on high Andean páramo vegetation in Colombia. Biodivers. Ecol. 2012, 4, 275-286. [CrossRef]

6. Peyre, G.; Lenoir, J.; Karger, D.N.; Gomez, M.; González, A.; Broennimann, O.; Guisan, A. The fate of páramo plant assemblages in the sky islands of the northern Andes. J. Veg. Sci. 2020, 31, 967-980. [CrossRef]

7. Aranguren-Riaño, N.; Guisande, C.; Ospina, R. Factors controlling crustacean zooplankton species richness in Neotropical lakes J. Plankton Res. 2011, 33, 1295-1303. [CrossRef]

8. Donato, J.; González, L.E.; Rodríguez, C.L. Ecología de dos Sistemas Acuáticos de Páramo; Academia Colombiana de Ciencias Exactas, Físicas y Naturales: Bogotá, Colombia, 1996.

9. Meneses-Ortegón, L.; Herrera, Y. Bacterioplancton de tres humedales altoandinos de la cordillera Oriental de Colombia. Rev. Biota Colomb. 2015, 16, 1-10.

10. Ramos, C.; Cárdenas, N.; Herrera, Y. Caracterización de la comunidad de Macrofitas acuáticas en lagunas del Páramo de La Rusia (Boyacá-Colombia). Cienc. Desarro. 2013, 4, 73-82.

11. Donato, J.; Jimenez, H.; Reynolds, C. Limnology in El Dorado: Some surprising aspects of the regulation of phytoplankton productive capacity in a high-altitude Andean lake (Laguna de Guatavita, Colombia). Rev. Biol. Trop. 2012, 60, 967-980. [CrossRef] [PubMed]

12. Pinilla-A, G.A.; Donato-R, J.C.; Rivera-R, C.A. Photosynthetic efficiency of phytoplankton in a tropical mountain lake. Caldasia 2006, 28, 57-66.

13. Zapata, A.; Rivera Rondón, C.A.; Donato, J. Dynamics of photosynthetic pigments in an Andean lake in Colombia. Lakes Reserv. Res. Manag. 2006, 11, 29-38. [CrossRef]

14. Zapata, A. Variaciones Diarias y Mensuales de la Productividad Primaria en un Lago Andino (Laguna de Guatavita. Cundinamarca). Master's Thesis, Pontificia Universidad Javeriana, Bogotá, Colombia, 2001.

15. Catalan, J.; Donato Rondón, J.C. Perspectives for an integrated understanding of tropical and temperate high-mountain lakes. J. Limnol. 2016, 75, 19. [CrossRef]

16. Spehn, E.M.; Liberman, M.; Korner, C. Land Use Change and Mountain Biodiversity; CRC Press: Boca Raton, FL, USA, 2006.

17. Sánchez-Cuervo, A.M.; Aide, T.M.; Clark, M.L.; Etter, A. Land Cover Change in Colombia: Surprising Forest Recovery Trends between 2001 and 2010. PLoS ONE 2012, 7, e43943. [CrossRef]

18. Tonneijck, F.H.; Jansen, B.; Nierop, K.G.J.; Verstraten, J.M.; Sevink, J.; De Lange, L. Towards understanding of carbon stocks and stabilization in volcanic ash soils in natural Andean ecosystems of northern Ecuador. Eur. J. Soil Sci. 2010, 61, 392-405. [CrossRef]

19. Steffen, W.; Richardson, K.; Rockström, J.; Cornell, S.E.; Fetzer, I.; Bennett, E.M.; Biggs, R.; Carpenter, S.R.; de Vries, W.; de Wit, C.A.; et al. Planetary boundaries: Guiding human development on a changing planet. Science 2015, 347, 1259855. [CrossRef]

20. Instituto Geográfico Agustín Codazzi. Datos Abiertos Cartografía y Geografía. Available online: https://geoportal.igac.gov.co/ contenido/datos-abiertos-cartografia-y-geografia (accessed on 11 November 2019).

21. Instituto de Investigación de Recursos Biológicos Alexander von Humboldt. Una Nueva Cartografía de los Páramos Colombianos: Diversidad, Territorio e Historia; Instituto Alexander von Humboldt: Bogotá, Colombia, 2013.

22. Registro Único de Áreas Protegidas (RUNAP). Runap en Cifras. Available online: https://runap.parquesnacionales.gov.co/cifras (accessed on 22 July 2021).

23. Instituto de Investigación de Recursos Biológicos Alexander von Humboldt. Base de Datos Geográfica de la Propuesta de Límite de los Complejos de Páramo a Escala 1:25.000. Available online: http://geonetwork.humboldt.org.co/geonetwork/srv/spa/ catalog.search\#/metadata/36139b13-b15e-445e-b44d-dd7a5dbe8185 (accessed on 22 July 2021).

24. Caballero, V.; Parra, M.; Bohorquez, A.R.M. Levantamiento de la cordillera oriental de Colombia durante el eoceno tardíooligoceno temprano: Proveniencia sedimentaria en el sinclinal de nuevo mundo, cuenca Valle medio del Magdalena. Bol. Geol. 2010, 32, 45 .

25. Gómez, J.; Nivia, A.; Montes, N.E.; Jiménez, D.M.; Tejada, M.L.; Sepúlveda, M.J.; Osorio, J.A.; Gaona, T.; Diederix, H.; Uribe, H.; et al. Mapa Geológico de Colombia. Escala 1:2'800.000, 2nd ed.; INGEOMINAS: Bogotá, Colombia, 2007.

26. APHA; AWWA; WEF. Standard Methods for the Examination of Water and Wastewater, 21st ed.; American Public Health Association: Washington, DC, USA, 2005; p. 1325. 
27. Thouret, J.-C.; Van der Hammen, T.; Salomons, B.; Juvigné, E. Paleoenvironmental Changes and Glacial Stades of the Last 50,000 Years in the Cordillera Central, Colombia. Quat. Res. 1996, 46, 1-18. [CrossRef]

28. Helmens, K. The Quaternary glacial record of the Colombian Andes. Dev. Quat. Sci. 2004, 2, 115-134. [CrossRef]

29. Angel, I.; Guzman, O.; Carcaillet, J. Pleistocene Glaciations in the Northern Tropical Andes, South America (Venezuela, Colombia and Ecuador). Cuad. Investig. Geogr. 2017, 43, 20. [CrossRef]

30. Catalan, J.; Curtis, C.J.; Kernan, M. Remote European mountain lake ecosystems: Regionalisation and ecological status. Freshw. Biol. 2009, 54, 2419-2432. [CrossRef]

31. Rivera-Rondón, C.A.; Catalan, J. Diatom diversity in the lakes of the Pyrenees: An iconographic reference. Limnetica 2017, 36, 127-396. [CrossRef]

32. Mosquera, P.V.; Hampel, H.; Vázquez, R.F.; Alonso, M.; Catalan, J. Abundance and morphometry changes across the highmountain lake-size gradient in the tropical Andes of Southern Ecuador. Water Resour. Res. 2017, 53, 7269-7280. [CrossRef]

33. Buytaert, W.; Célleri, R.; De Bièvre, B.; Cisneros, F.; Wyseure, G.; Deckers, J.; Hofstede, R. Human impact on the hydrology of the Andean páramos. Earth-Sci. Rev. 2006, 79, 53-72. [CrossRef]

34. Castro, C.; Agualimpia, Y.; Sánchez, F. Modelo climático de los páramos de la cordillera Oriental colombiana aplicado a regímenes de temperatura del suelo. Perspect. Geogr. 2016, 21, 33-62. [CrossRef]

35. Schmidt-Mumm, U.; Vargas Ríos, O. Comunidades vegetales de las transiciones terrestre-acuáticas del páramo de Chingaza, Colombia. Rev. Biol. Trop. 2012, 60, 35-64. [CrossRef] [PubMed]

36. Curtis, C.J.; Juggins, S.; Clarke, G.; Battarbee, R.W.; Kernan, M.; Catalan, J.; Thompson, R.; Posch, M. Regional influence of acid deposition and climate change in European mountain lakes assessed using diatom transfer functions. Freshw. Biol. 2009, 54, 2555-2572. [CrossRef]

37. Van Colen, W.R.; Mosquera, P.; Vanderstukken, M.; Goiris, K.; Carrasco, M.-C.; Decaestecker, E.; Alonso, M.; León-Tamariz, F.; Muylaert, K. Limnology and trophic status of glacial lakes in the tropical Andes (Cajas National Park, Ecuador). Freshw. Biol. 2017, 62, 458-473. [CrossRef]

38. Rivera-Rondón, C.A.; Catalan, J. The ratio between chrysophycean cysts and diatoms in temperate, mountain lakes: Some recommendations for its use in paleolimnology. J. Paleolimnol. 2017, 57, 273-285. [CrossRef]

39. Rooney, N.; Kalff, J.; Habel, C. The Role of Submerged Macrophyte Beds in Phosphorus and Sediment Accumulation in Lake Memphremagog, Quebec, Canada. Limnol. Oceanogr. 2003, 48, 1927-1937. [CrossRef]

40. Sayer, C.D.; Burgess, A.M.Y.; Kari, K.; Davidson, T.A.; Peglar, S.; Yang, H.; Rose, N. Long-term dynamics of submerged macrophytes and algae in a small and shallow, eutrophic lake: Implications for the stability of macrophyte-dominance. Freshw. Biol. 2010, 55, 565-583. [CrossRef]

41. Psenner, R.; Catalan, J. Chemical composition of lakes in crystalline basins: A combination of atmospheric deposition, geologic background, biological activity and human action. In Limnology Now: A Paradigm of Planetary Problems, 1st ed.; Margalef, R., Ed.; Elsevier Science: Amsterdam, The Netherlands, 1994; pp. 255-314.

42. Rivera-Rondón, C.A.; Catalan, J. Diatoms as indicators of the multivariate environment of mountain lakes. Sci. Total Environ. 2020, 703, 135517. [CrossRef] [PubMed]

43. Cantonati, M.; Lange-Bertalot, H. Diatom monitors of close-to-pristine, very-low alkalinity habitats: Three new eunotia species from springs in nature parks of the south-eastern alps. J. Limnol. 2011, 70, 209-221. [CrossRef]

44. Canham, C.D.; Pace, M.L.; Weathers, K.C.; McNeil, E.W.; Bedford, B.L.; Murphy, L.; Quinn, S. Nitrogen deposition and lake nitrogen concentrations: A regional analysis of terrestrial controls and aquatic linkages. Ecosphere 2012, 3, art66. [CrossRef]

45. Davidson, T.A.; Jeppesen, E. The role of palaeolimnology in assessing eutrophication and its impact on lakes. J. Paleolimnol. 2013, 49, 391-410. [CrossRef]

46. Vadeboncoeur, Y.; Peterson, G.; Vander Zanden, M.J.; Kalff, J. Benthic algal production across lake size gradients: Interactions among morphometry, nutrients, and light. Ecology 2008, 89, 2542-2552. [CrossRef]

47. Donato, J. Phytoplankton of Andean Lakes in Northern South America (Colombia); Witkowski, A., Ed.; A.R.G. Gantner Verlag K. G.: Ruggell, Liechtenstein, 2010; Volume 11, p. 419.

48. Catalan, J.; Camarero, L.; Felip, M.; Pla, S.; Ventura, M.; Buchaca, T.; Bartumeus, F.; de Mendoza, G.; Miró, A.; Casamayor, E.; et al. High mountain lakes: Extreme habitats and witnesses of environmental changes. Limnetica 2006, 25, 551-584.

49. Catalan, J.; Bartrons, M.; Camarero, L.; Grimalt, J. Mountain Waters as Witnesses of Global Pollution. In Living with Water: Targeting Quality in a Dynamic World; Pechan, P., de Vries, G.E., Eds.; Springer: New York, NY, USA, 2013; pp. 31-67. [CrossRef]

50. Williams, J.J.; Lynch, J.A.; Saros, J.E.; Labou, S.G. Critical loads of atmospheric N deposition for phytoplankton nutrient limitation shifts in western U.S. mountain lakes. Ecosphere 2017, 8, e01955. [CrossRef]

51. Bradley, R.S.; Vuille, M.; Diaz, H.F.; Vergara, W. Threats to water supplies in the tropical andes. Science 2006, 312, 1755-1756. [CrossRef] [PubMed]

52. Striebel, M.; Schabhüttl, S.; Hodapp, D.; Hingsamer, P.; Hillebrand, H. Phytoplankton responses to temperature increases are constrained by abiotic conditions and community composition. Oecologia 2016, 182, 815-827. [CrossRef] [PubMed]

53. Burns, N.; Gibbs, M.; Hickman, M. Measurement of oxygen production and demand in lake waters. N. Z. J. Mar. Freshw. Res. 1996, 30, 127-133. [CrossRef]

54. Fang, X.; Stefan, H.G. Simulations of climate effects on water temperature, dissolved oxygen, and ice and snow covers in lakes of the contiguous U.S. under past and future climate scenarios. Limnol. Oceanogr. 2009, 54, 2359-2370. [CrossRef] 
55. Lewis, W.M.J. Tropical lakes: How latitude makes a difference. In Perspectives in Tropical Limnology; Schiemer, F., Boland, K.T., Eds.; SPB Academic Publishing: Amsterdam, The Netherlands, 1996; pp. 43-64.

56. Beklioglu, M.; Altinayar, G.; Tan, C. Water level control over submerged macrophyte development in five Mediterranean Turkey. Arch. Hydrobiol. 2006, 166, 535-556. [CrossRef]

57. Zhao, D.; Jiang, H.; Cai, Y.; An, S. Artificial regulation of water level and its effect on aquatic macrophyte distribution in Taihu Lake. PLoS ONE 2012, 7, e44836. [CrossRef]

58. Catalan, J.; Ninot, J.M.; Aniz, M.M. The High Mountain Conservation in a Changing World. In High Mountain Conservation in a Changing World; Catalan, J., Ninot, J.M., Aniz, M.M., Eds.; Springer: Cham, Switzerland, 2017; pp. 3-36. [CrossRef]

59. Bennion, H.; Battarbee, R.W.; Sayer, C.D.; Simpson, G.L.; Davidson, T.A. Defining reference conditions and restoration targets for lake ecosystems using palaeolimnology: A synthesis. J. Paleolimnol. 2011, 45, 533-544. [CrossRef]

60. Ventura, M.; Tiberti, R.; Buchaca, T.; Buñay, D.; Sabás, I.; Miró, A. Why should we preserve fishless high-mountain lakes? In High Mountain Conservation in a Changing World; Catalan, J., Ninot, J.M., Aniz, M.M., Eds.; Springer: Cham, Switzerland, 2017; pp. 181-206.

61. Herrera-Martínez, Y.; Paggi, J.; Garcia, C. Cascading effect of exotic fish fry on plankton community in a tropical Andean high mountain lake: A mesocosm experiment. J. Limnol. 2017, 76, 397-408. [CrossRef] 